Primljen / Received: 19.2.2013. Ispravljen / Corrected: 11.5.2013.

Prihvaćen / Accepted: 22.5.2013. Dostupno online / Available online: 10.6.2013.

\section{Seismic behaviour of buildings founded on thermal insulation layer}

\section{Authors:}

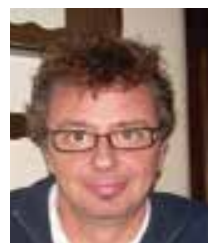

Prof. Vojko Kilar, PhD. CE University of Ljubljana Faculty of Architecture vojko.kilar@fa.uni-lj.si

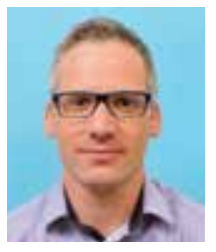

Asst.Prof. David Koren, PhD. CE University of Ljubljana Faculty of Architecture david.koren@fa.uni-lj.si

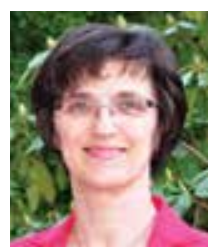

Prof. Martina Zbašnik-Senegačnik, PhD AR University of Ljubljana Faculty of Architecture martina.zbasnik@fa.uni-lj.si

\section{Vojko Kilar, David Koren, Martina Zbašnik-Senegačnik}

\section{Seismic behaviour of buildings founded on thermal insulation layer}

Thermal insulation under the building foundation plate or under the strip foundations prevents the thermal bridge on the contact between the building and supporting terrain and reduces the energy consumption in modern passive and low energy houses. In the paper the seismic behaviour of buildings with different heights, floor plan dimensions, on different soil conditions and on different thermal insulation layers have been analysed. The results of simplified seismic analyses have shown, that the potentially negative influences of inserting the insulation under the foundation plate could be expected only for buildings with more than two or three storeys.

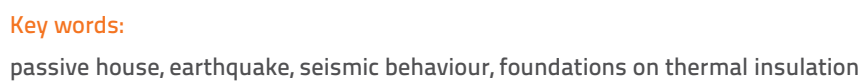

Prethodno priopćenje

\section{Vojko Kilar, David Koren, Martina Zbašnik-Senegačnik}

\section{Ponašanje zgrada temeljenih na toplinskoj izolaciji pri potresu}

Termoizolacija postavljena ispod temeljne ploče gradevine ili ispod trakastog temelja sprečava pojavu toplinskog mosta na kontaktu između građevine i temeljnog tla te smanjuje potrošnju energije kod modernih pasivnih i niskoenergetskih kuća. U ovom se radu analizira seizmičko ponašanje građevina raznih visina i tlocrtnih katnih dimenzija, za razne uvjete tla i za razne vrste termoizolacijskih slojeva. Rezultati pojednostavljenih seizmičkih analiza pokazuju da se potencijalno negativni utjecaji postavljanja izolacije ispod temeljne ploče mogu očekivati samo kod građevina koje se sastoje od više od dva ili tri kata.

Ključne riječi:

pasivna kuća, zemljotres, seizmičko ponašanje, temelji na termoizolaciji

Vorherige Mitteilung

Vojko Kilar, David Koren, Martina Zbašnik-Senegačnik

\section{Seismisches Verhalten auf Wärmedämmungsschichten fundierter Gebäude}

Unter Fundationsplatten oder Streifenfundamenten angelegte Wärmedämmung verhindert thermische Brücken am Kontakt zwischen Gebäude und Unterboden und senkt den Energieverbrauch in modernen Passiv- und Niedrigenergiehäusern. In dieser Arbeit ist das seismische Verhalten von Gebäuden verschiedener Bauhöhen und Abmessungen im Grundriss, für unterschiedliche Bodenverhältnisse, auf verschiedenen Wärmedämmungsschichten untersucht worden. Die Resultate der vereinfachten seismischen Analysen haben gezeigt, dass potenzielle, durch die Anwendung der Isolationsschichten unter den Fundamenten bedingte, negative Einflüsse nur für Gebäude mit mehr als zwei oder drei Stockwerken erwartet werden können. 


\section{Introduction}

Thermal insulation is the most effective element of measures to reduce energy consumption for heating in buildings. Energy efficiency requirements have been growing more stringent since the first energy crisis in 1973, when heat transfer via the external elements of buildings was mentioned for the first time. This has graduallyreduced, with aresulting increase in the minimum thermal insulation of the building. The energy performance of buildings has benefited from energy-efficient heating and ventilation systems, windows and doors with thermally insulating frames and glass, thicker thermal insulation, improved characteristics, and so on [1]. The passive house standard has been developed - this is currently the optimal energy-efficient house [2]. In Europe 39,390 passive houses had been built by the end of 2011 [3], and their number continues to grow dramatically.

In the last two decades, researches, analysis, simulations, measurements, etc. have looked at passive houses from a variety of viewpoints. Numerous authors cover their energy performance and the influence of the structure of the building envelope on heat losses [4], types of thermal bridges and their influence on energy performance [5], the incorporation of internal heat sources in the energy balance [6], and optimisation of heating and ventilation [7]. Comfort is an added value of passive houses that is confirmed by numerous user experience surveys $[4,8,9,10]$.

Answers to most questions relating to passive houses can be found in scientific literature. At present, however, it is not possible to find research dealing with the field of the thermal insulation below the foundation slab in earthquake risk areas what the profession proposes to avoid thermal bridges at the contact of the building to the ground. We assume that the solutions offered in seismically inactive areas $[4,5]$ cannot be transferred elsewhere without first carrying out additional verifications. Although destructive earthquakes are rare, it is frequently the case that catastrophic earthquake damage to buildings is the result of planning and construction errors.

The main goal of the paper is to identify the possible negative influences of already developed technical solutions for preventing thermal bridges with inserting the insulation layer under the foundation plate or strip foundations and to propose the structural measures and limitations for their applications in earthquake prone regions.

\section{Passive house}

The annual heating energy demand in passive house [11] may not exceed $15 \mathrm{kWh} /\left(\mathrm{m}^{2} \mathrm{a}\right)$. In order to achieve such low consumption, the building must have a well thermally insulated and airtight envelope without thermal bridges. In this way, transmission heat losses through the envelope are kept very low. The building must have a system of controlled ventilation with heat recovery, which also helps reduce ventilation heat losses. With suitable planning heating loads do not exceed $10 \mathrm{~W} / \mathrm{m}^{2}$ and can be covered by so-called air heating. A traditional heating system is no longer necessary [4].
One of the basic requirements for the treatment of the passive house standard is "construction without thermal bridges". A structure is thermal bridge free when linear thermal transmittance $\psi \leq 0,01 \mathrm{~W} /(\mathrm{mK}$ ) and internal surface temperatures (at a minimum outside air temperature of $-10^{\circ} \mathrm{C}$, ground temperature of $+10^{\circ} \mathrm{C}$ and inside air temperature of $+20^{\circ} \mathrm{C}$ ) are always above $13^{\circ} \mathrm{C}$ [5]. Thermal bridges cause various problems in buildings [12]:

- Increased consumption of energy for heating,

- Reduced thermal comfort (cold surfaces on the envelope cause faster movement of air, which is felt as a draught),

- Appearance of condensation in the area of thermal bridges and the formation of mould.

The key points where thermal bridges usually occur are balconies and projecting roofs that are part of the floor structure, connections of roof to wall, windows and entrance doors, and the contact of the building with the ground or unheated part (e.g. a cold basement). In a passive house, these junctions must be implemented without thermal bridges. The thermal envelope must be uninterrupted (Figure 1).

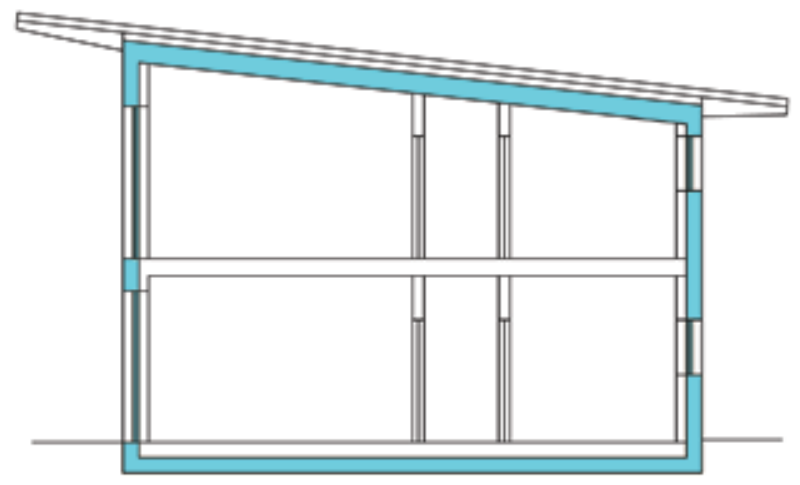

Figure 1. The thermal envelope of the building must be uninterrupted

The majority of problematic junctions can be resolved through interruption of the thermal bridge by installing thermal insulation between the elements of the supporting structure. Eliminating the thermal bridge at the point of contact between the building and the ground is more difficult [13]. Experts propose two solutions [5]:

- Interruption of the thermal bridge at the junction of the outside wall with the strip foundation or foundation slab by means of a so-called insulation base (in the thickness of the thermal insulation - Figure 2) made of a material with suitable compressive strength and thermal conductivity $\lambda \leq 0.12 \mathrm{~W} /(\mathrm{mK}))$ [13]. Suitable materials for the isolation base include aerated concrete, light concrete, foam glass and extruded polystyrene (XPS).

- Installation of thermal insulation with suitable compressive strength below the foundation slab or strip foundations (Figure 3). The materials most frequently used for this purpose are XPS and foam glass granulate, EPS (conditionally - only for family houses, with quality hydroinsulation, maximum compressive strength $300 \mathrm{kPa}$ ). 


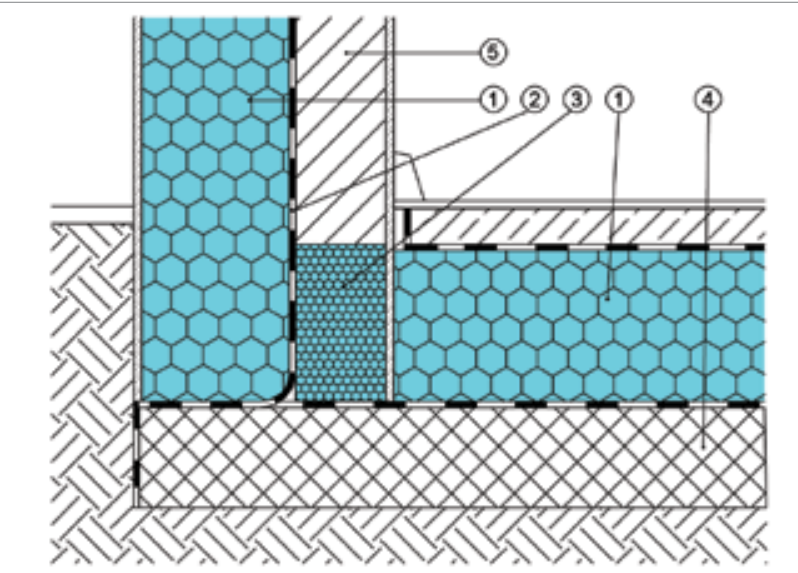

LEGEND: 1 - thermal insulation; 2 - hydro-insulation; 3 - loadbearing thermal insulation element $(\lambda \leq 0.12 \mathrm{~W} /(\mathrm{mK})$; 4-RC slab; 5 - masonry wall

Figure 2. Contact of outside wall and floor slab - interruption of thermal bridge by means of insulation base

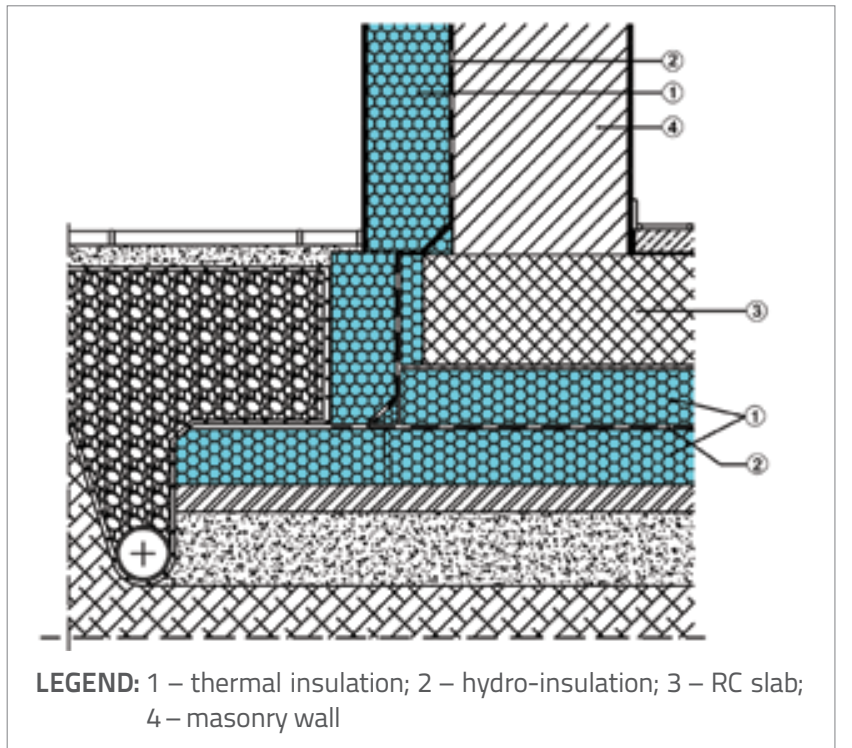

Figure 3. Contact of outside wall and floor slab resting on thermal insulation - no thermal bridge

In those parts of Europe in which passive houses have already become established practice, earthquakes are for the most part unknown and therefore these solutions are suitable. In recent years, however, the passive house standard has slowly been gaining ground in areas where earthquakes (including strong earthquakes) are frequent, such as Spain, Portugal, Italy, Greece, Croatia and Slovenia. The suitability of such details in earthquake areas needs to be verified, and appropriate solutions found. The paper continues with the description of the used models and methods for numerical simulations, which (under the given assumptions) enable the calculation of stresses and deformations in thermal insulation layer under the foundation plate or under the strip foundations. A parametric study tries to answer the question what are the heights, weights and slenderness of buildings that can be safety transferred from seismic inactive regions to seismic active ones.

\section{Seismic response of buildings founded on thermal insulation layer}

\subsection{Problem description}

Passive houses can be built of massive materials (e.g. masonry, concrete) or lighter wood panels or wood frame systems which are more environment friendly and faster to build $[14,15]$. For all different building technologies the technical solutions transferred from North or Middle Europe suggest also the foundation on thermal insulation layer. Our numerical simulations have shown that for smaller (e.g. family) houses the foundation on thermal insulation layer is neither structurally, nor seismically problematic, especially if the building has an underground basement. For higher/ heavier/slenderer buildings without basement storey, however, the strong earthquake loading might have much bigger influence.

On seismically inactive grounds an alternative for solving a thermal bridge problem is the usage of so called load-bearing thermal insulation elements (pedestals), which are mounted at the base of walls in order to prevent the thermal bridge between the load bearing wall and supporting ground. From the seismic resistant point of view every discontinuation of load bearing walls or columns with any thermal insulation material or similar device significantly reduces the horizontal stiffness and strength and might become a source of high risk during a strong earthquake. For this reason the usage of such load bearing substitution elements (Figure 2) is not allowed without carrying out additional verifications for seismic load combinations. In the case of buildings based on thermal insulation layer in seismic prone areas (Figure 3) an additional caution should be given especially to the following aspects:

- The earthquake induced shear or compression stresses should be smaller as corresponding nominal design strengths of thermal insulation layer.

- The earthquake induced shear or compression deformations should be smaller as prescribed allowable deformations of thermal insulation.

- Due to the changed vibration modes of building based on thermal insulation every uncontrolled increase of earthquake demand on the superstructure should be prevented.

It should be pointed out that by inserting the flexible layers of thermal isolation between the RC foundation plate and levelling concrete on the ground, we prolong the fundamental period of the structure, because the building on isolation layer oscillates slower as on a firm ground $\left(T_{\text {i(solated) }}>T_{\text {n(onisolated) }}\right)$. The fundamental periods are additionally increased due to rocking effects which are a consequence of vertical deformability of insulation layer. Most of passive houses are up to two stories 

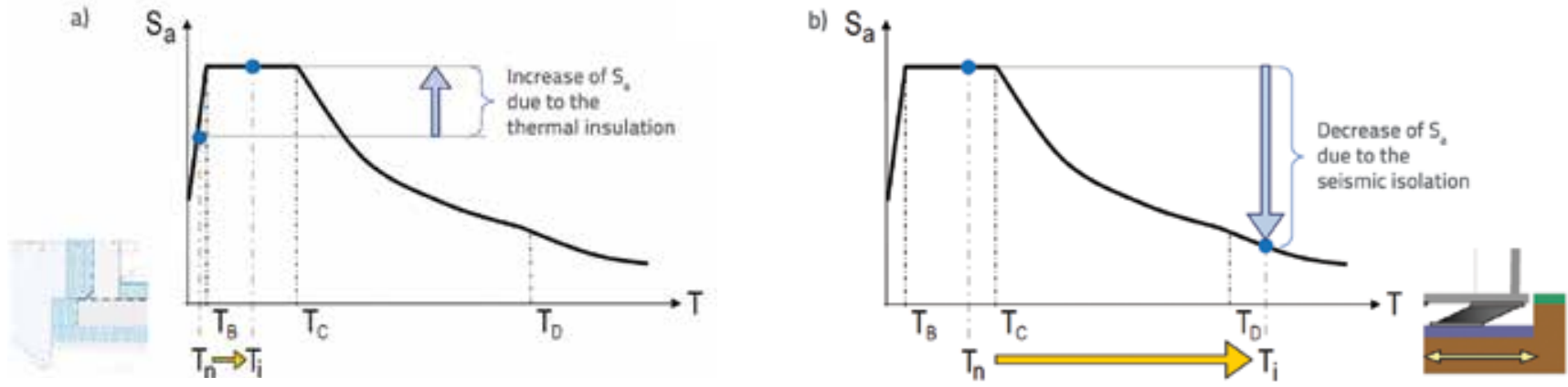

Figure 4. Roof accelerations of the superstructure on: a) thermal insulation (XPS); b) conventional seismic isolation (rubber bearings) under the foundation plate

high low rise buildings with short fundamental periods $\left(T_{n}\right.$ $<0.1 \mathrm{~s}$ ), which could be further elongated by insertion of thermal isolation layer and thus moved into resonance part of the design response spectrum (into the period of constant accelerations - see Figure 4). As it can be seen from Figure 4a, in such cases the expected top accelerations of the structure can be raised up to two or three times in comparison to a fixed base one. Such increase might lead to the damage of the superstructure or its content and should not be ignored. However, if the superstructure fundamental period $T_{n}$ is already within the plateau of constant accelerations, the inserting of insulation under the foundation plate elongates the structural period into descending branch $\left(T_{i}>T_{c}\right)$ and consequently the forces on the structure are reduced (Figure 4b). Only in this case the thermal insulation layer acts as the seismic base isolation system [16-19] and reduces the earthquake induced forces. It can be concluded that the negative effect of thermal insulation can be expected only if the fundamental period of the passive building [20] is shorter than period $T_{C}$ from Eurocode 8 elastic spectrum (0.4 - $0.8 \mathrm{~s}$ ).

\subsection{Simplified analysis of shear and edge compressive stresses in the thermal insulation layer}

The horizontal earthquake loads in combination with vertical loads cause horizontal shear stresses and vertical compression stresses in thermal insulation layer. At the most exposed edge of foundation plate the vertical stresses due to horizontal forces are added up to the stresses caused by vertical loads. Under these edges the vertical stresses in the insulation layer under the foundation plate can be therefore significantly increased. For this reason we can expect that during a strong earthquake the insulation layer will be contracted at one side and lifted on the other one (Figure 5). This phenomenon is known in the literature as "rocking" effect [21-23]. In order to prevent the non-residual deformation and permanent damage of the insulation layer, the edge compressive strength should be kept within nominal design strength boundaries determined with compressive test experiments of the used thermal insulation material. In the analyses presented in this paper we have used only the extruded polystyrene (XPS), which is a product of Fibran
Nord and is readily available in most European countries. The necessary material data and modulus of elasticity have been obtained by the tests described in section 4.1. The conclusions made will be therefore limited to the thermal insulation materials with similar mechanical properties. The stress control under foundation plate was made by simplified seismic analysis based on the equivalent horizontal forces method according to Eurocode 8. It was assumed that the building layout is a rectangle with dimensions $a / b$, with masses concentrated on the floor levels and that building is based on the flexible layer of thermal insulation under the rigid foundation plate. The maximum edge compressive stresses ( $\sigma_{\text {edge }}$ ) and shear stresses $(\tau)$ have been calculated according to the following well known static equations (Figure 5). They can be found for example in $[26,27])$ :

$\sigma_{\text {edge }}=\frac{\mathrm{N}}{\mathrm{A}}$

Force applied in the building centre of gravity (Figure 5.a)

$\sigma_{\text {edge }}=\frac{\mathrm{N}}{\mathrm{A}} \pm \frac{M}{W} \quad$ Eccentric force inside the core of a cross section (j) (Figure 5.b)

$\sigma_{\text {edge }}=\frac{2 \cdot \mathrm{F}}{3 \cdot \mathrm{c} \cdot \mathrm{B}} \quad$ Eccentric force outside the core of a cross section (j) (Figure 5.c)

$\tau=\frac{\mathrm{F}_{\mathrm{h}}}{\mathrm{A}_{\mathrm{s}}}$

where:

$N$ - axial load on foundation plate,

$M$ - overturning moment (at the contact with XPS layer) caused by earthquake load,

A - area of the foundation plate,

$W$ - bending stress modulus of foundation plate,

$F$ - eccentric compressive force,

$C$ - distance of eccentric force $F$ from the foundation edge,

$B$ - dimension of foundation plate in the direction in which acts the bending moment $\mathrm{M}$,

$F_{h}$ - total earthquake base shear computed from the top acceleration from elastic spectrum and total mass of the building in the seismic design limit state

$A_{s}$ - shear area (for rectangular $A_{s}=1.5 \mathrm{~A}$ ). 


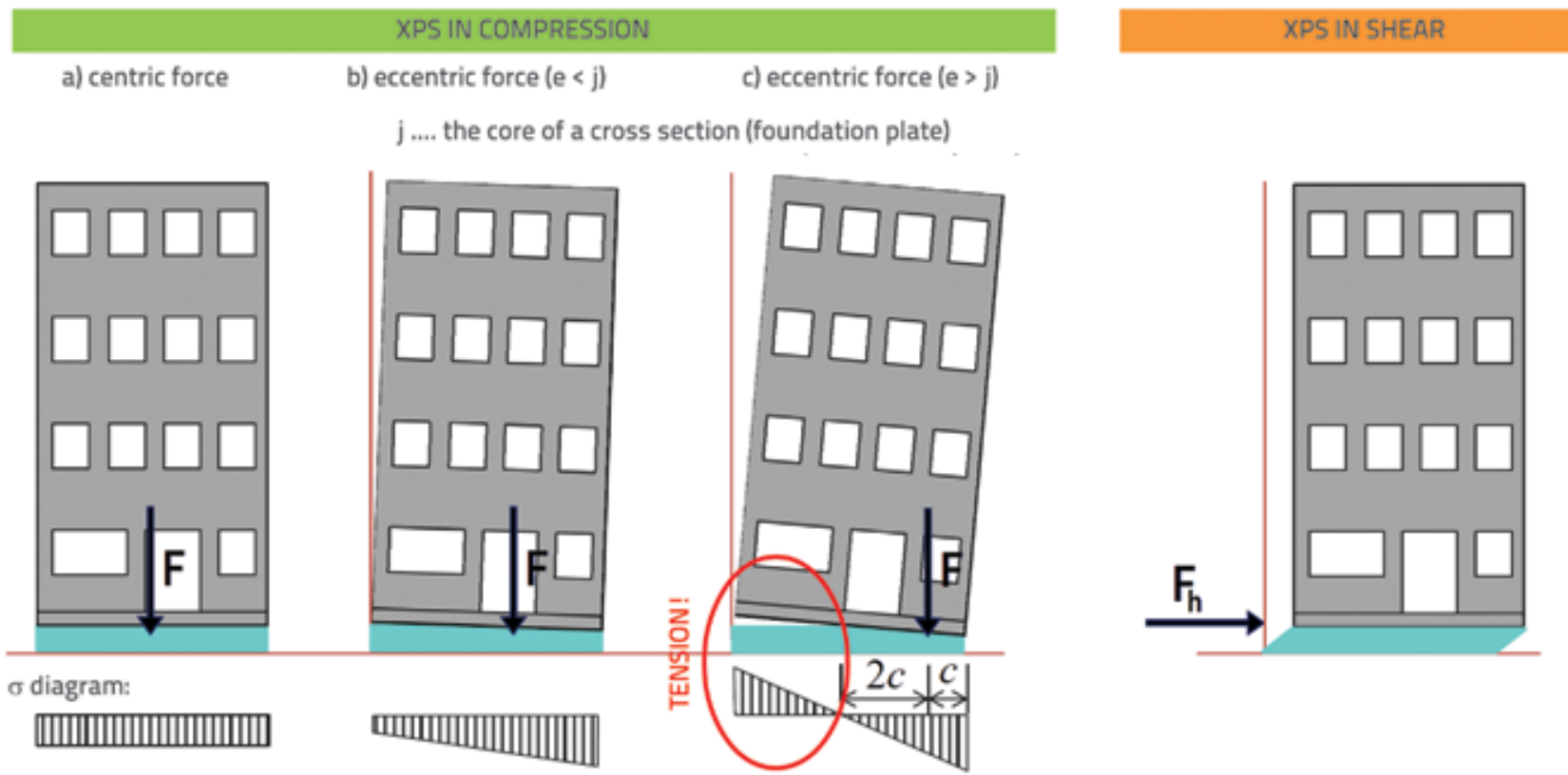

Figure 5. Behaviour of a rigid building structure on a flexible base (e.g. XPS thermal insulation) under the foundation plate

Basic assumptions for simplified seismic analysis are as follows:

- The deformability of the superstructure has not been considered. The whole superstructure with the RC foundation plate is modelled as elastically restrained rigid body. The stiffness of flexural and shear springs have been determined from the dimensions and properties of the insulation layer.

- The structural layout is regular without irregularities in plan or elevation (e.g. without distinctive balconies), the load bearing elements are symmetrically distributed in the floor plan.

- All floor plans including the foundation plate and the insulation layer under it have equal dimensions (a/b).

- The insulation layer might be distributed only partly under the foundation plate in order to simulate the strip foundations.

- The masses for earthquake loading case are calculated from the uniformly distributed loads which are given separately for each storey level. The mass of base level is also taken into account.

- EC8 elastic response spectrum [29] from National Annex (soil type, characteristic periods) given for Slovenia [30] have been considered for definition of earthquake loading.

- Vertical stiffness of XPS layer is calculated from its thickness and elastic modulus in compression. The structure is modelled as elastically restrained rigid cantilever, its fundamental period have been determined as [31]:

$T^{2}=T_{x}^{2}+T_{\phi}^{2}$ or $\frac{1}{\omega^{2}}=\frac{1}{\omega_{x}^{2}}+\frac{1}{\omega_{\phi}^{2}}$

where $\omega_{x}$ denotes the frequency due to horizontal displacement of the building and $\omega_{\phi}$ the rotational frequency of foundation plate on the XPS layer. The frequencies have been determined as:
$\omega_{x}^{2}=\frac{k_{x}}{M}, \omega_{\phi}^{2}=\frac{k_{\phi}}{J}$

where $k_{x}$ is the stiffness of the horizontal spring, $k_{\phi}$ the stiffness of the rotational spring and $M$ the mass of the whole structure. J denotes the mass inertia moment which is calculated from concentrated masses of stories $\left(m_{i}\right)$ on the given floor level heights $\left(h_{\mathrm{i}}\right)$ :

$J=\sum_{i} m_{i} h_{i}$

- The shear stress of the XPS layer is determined as a product of the shear modulus $(G)$ and the shear strain $(\gamma)$ of thermal insulation layer.

- There is no sliding at contact between XPS and hydroinsulation.

- The effects of two directional ground motion components have been considered according to Eurocode 8 [29], clause 4.3.3.5.1(3).

For selected models of passive houses with different weights and heights and different floor plan layouts we conducted a parametric study by observing the following parameters (the results are presented in section 4 ):

- Fundamental period of the structure in longitudinal and in transversal direction.

- Actual eccentricity in longitudinal and in transversal direction (M/N).

- Maximum edge compressive stresses in the XPS layer. If the stress sign is negative, the object general stability condition is validated (e $>50 \%$ ).

- Maximum shear stresses in the XPS layer. 
Table 1. Considered values $\left[\mathrm{kN} / \mathrm{m}^{2}\right]$ of vertical loads in seismic design limit state for different structural materials

\begin{tabular}{|l|c|c|}
\hline Structure & $\begin{array}{c}\text { Ground floor } \\
\text { (without self-weight of RC foundation plate) }\end{array}$ & Storeys \\
\hline RC plates + RC walls & 7 & 16 \\
\hline Brick masonry walls + light-weight slabs & 5 & 6 \\
\hline Wood (KLH plates and walls) & 3.5 & 6 \\
\hline
\end{tabular}

Table 2. Material characteristics of the XPS according to the producer's (Fibran Nord) data

\begin{tabular}{|l|c|c|c|c|c|}
\hline \multicolumn{1}{|c|}{ Type of XPS } & XPS 300-L & XPS 400-L & XPS 500-L & XPS 600-L & XPS 700-L \\
\hline $\begin{array}{l}\text { Characteristics of XPS } \\
\sigma_{\text {nom }}[\mathrm{kPa}] \text { at } 10 \% \text { deformation }\end{array}$ & 300 & $400(469)$ & 500 & 600 & 700 (753) \\
\hline Elastic modulus $E[\mathrm{MPa}]$ & 20 & $25(23.4)$ & 30 & 35 & 40 (34.9) \\
\hline Shear strength $\tau_{\text {nom }}[\mathrm{kPa}]$ & 150 & $150(136)$ & 150 & 150 & $150(209)$ \\
\hline Shear modulus $G[\mathrm{MPa}]$ & 2.6 & $2.6(4.5)$ & 2.6 & 2.6 & $2.6(7.4)$ \\
\hline
\end{tabular}

Notice: In table the average measured (monotonic tests [28]) values for the XPS 400-L and 700-L are provided "in parentheses"

- Maximum horizontal displacement of the XPS layer (allowable elastic limit displacement was set to $2 \%$ of thickness of the XPS layer).

- Maximum horizontal displacement at the top of the building (allowable displacement was set to $0.2 \%$ of the building height [30]).

\section{Parametric study}

\subsection{Input data}

In the parametric study the effects of different parameters (mass, plan layout dimensions, number of storeys, soil types and XPS characteristics) on the seismic vulnerability of selected buildings founded on the XPS layer have been analysed by the simplified static analysis described in the previous section. The superstructure together with the base foundation slab was assumed to behave as a fully rigid block. Consequently, the only input data about the building were plan dimensions, heights and storey masses (loads). Three different structural materials were considered (Table 1). All investigated models were assumed to be without basement storey. According to the Eurocode 8 [29] the dead load and $30 \%$ of the live load $\left(\mathrm{q}_{\mathrm{k}, 100 \%}=\right.$ $3.5 \mathrm{kN} / \mathrm{m}^{2}$ ) were considered in the seismic design limit state. In the presented phase of the research the investigated models were wall structures only. The mass of the load bearing walls was included as a uniform gravity area load. The considered area portion of walls was chosen equal to $10 \%$ of total plan area $\left(A_{\text {wall }} /\right.$ $A_{\text {plan,gross }}=10 \%$ ) and the assumed storey height equal to $3.0 \mathrm{~m}$ was considered. Three different rectangular plan layouts $(\mathrm{b} / \mathrm{a}=$ $6 / 8,8 / 14$ and $14 / 40 \mathrm{~m}$ ) of the superstructure were analysed and equal areas were considered also for the foundation slabs and the XPS layers below. The damping was assumed equal to $5 \%$ of critical damping. In the study different seismic intensities and various soil types (A-E according to EC8) were analysed. In the presented paper only the results based on the maximum design ground acceleration in Slovenia $\left(\mathrm{a}_{\mathrm{g}}=0.25 \mathrm{~g}\right)$ are presented. The thickness of the reinforced concrete (RC) foundation slab $(30 \mathrm{~cm})$ and the thickness of the XPS layer $(20 \mathrm{~cm})$ below were equal in all investigated models. The storey height $(3.0 \mathrm{~m})$ was constant along the whole height of the building $(\mathrm{H})$, where the latter was measured from the bottom edge of the XPS up to the top (roof) of the building.

For material characteristics of the XPS the conservative values according to the producer's Fibran Nord data [32] were assumed. Only the products applicable for foundation slabs were analysed (Table 2). The producer provides the XPS plates of different nominal compressive strengths (from 300 to $700 \mathrm{kPa}$ ) and of different vertical stiffness. It should be noted that the XPS material behaves elastically at small deformations (up to 1-2 $\%)$, after that its behaviour is completely inelastic. In production the behaviour of the XPS in compression is regularly controlled (according to EN 826 [24]), while the behaviour in shear (according to EN 12090 [25]) is actually not yet investigated. Figure 6 shows the results of monotonic compressive and shear tests of cube specimens with the dimension $\mathrm{a}=12 \mathrm{~cm}$ (XPS 400-L) and $\mathrm{a}=$ $10 \mathrm{~cm}$ (XPS 700-L). In the analysis the material characteristics of XPS were assumed as design values (partial safety factor for material was taken as being equal to 1.0). For shear strength $(\tau)$ and shear modulus $(G)$ the producer provides equal values for all XPS strength classes. Consequently, for selected building the translational period of vibration (horizontal stiffness) was equal irrespective of the XPS class. The difference appeared in the behaviour in compression (elastic modulus $E$ of the XPS is 20 $\mathrm{MPa}$ and $40 \mathrm{MPa}$, for the XPS 300-L and XPS 700-L, respectively), what effects the total period of vibration. 

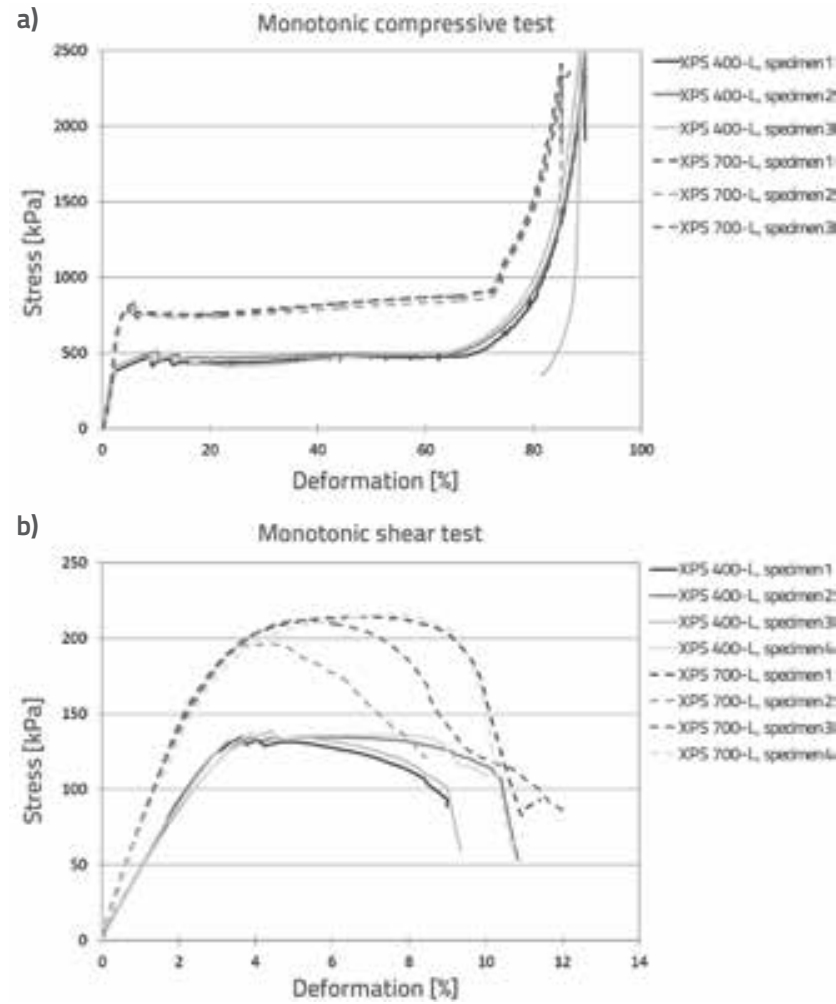

Figure 6. Behaviour of the XPS material in compression and in shear [28]

\subsection{Results}

In Figures 7-11 the selected results of the parametric study are presented. The results are presented in terms of periods of vibrations in the shorter plan dimension (b), maximum stresses and displacements in relation to the number of storeys, material and plan layout dimensions of the superstructure founded on different soil types and different XPS layers. Only the results of the relevant cases are presented i.e. the cases where the resultant vertical force lies within the plan of the building and its stability is thus not affected (an overturning does not occur). In other words, only the cases where the obtained eccentricity (e) is smaller than 50 $\%$ of the shorter plan dimension (b) are shown. For this reason the obtained curves have different lengths in sense of the allowed number of storeys. In all presented cases, except the results shown in Figure 9, it was considered that the building is founded on the RC foundation slab lying on the XPS layer of the same plan dimensions as those of the superstructure (for the XPS area the $100 \%$ of the superstructure's total plan area was assumed).

In Figures 7 in 8 the effects of different floor plan layout dimensions and materials of the superstructure founded on selected XPS (400-L) layer and selected soil type (A) are presented. It can be seen that the calculated periods of vibration are almost in all analysed cases larger than the characteristic period of the ground motion $T_{B}=0.10 \mathrm{~s}$ (soil $A$ ), where $T_{B}$ is the lower limit of the period of the constant spectral acceleration branch according to the EC8 spectrum. This means that in case of applying the XPS layer under the foundation slab the system's period of vibration was lengthened and it reached the spectrum plateau (constant acceleration range) where the seismic forces are larger. As could be expected, more critical response was obtained in case of heavy (reinforced concrete) structures. In some cases of slender structures (i.e. with the small ratio between the height and the plan dimensions of the building) the stability control (overturning) proved to be more critical than the control of maximum compressive stresses in the XPS. On the contrary, for larger plan layouts (e.g. 14/40 $\mathrm{m}$ ) the latter control (stresses in the XPS) was almost always critical.

Observing the obtained stresses in the XPS we can conclude that for the plan layout $6 / 8 \mathrm{~m}$ the maximum acceptable number of storeys is 2 (RC, masonry) or 3 (wood), for the plan layout $8 / 14 \mathrm{~m}$ this number is 2 (RC) or 3 (masonry, wood), and for the plan layout $14 / 40 \mathrm{~m}$ the maximum number of storeys is limited to 4 (RC), 5 (masonry) or 6 (wood). From the curves presenting the maximum compressive stresses in the XPS it should be noted, that while a certain higher level (around 200 $\mathrm{kPa}$ ) of the edge compressive stress is reached, the stresses rapidly increase with the increasing number of storeys. Because of the exceeded nominal compressive strengths $\left(\sigma_{\text {nom }}\right)$ of the XPS the upgrading of the building with additional storeys is not possible. Observing the obtained maximum shear stresses and maximum horizontal displacements at the XPS layer and at the top of the building (Figure 8) the shear stresses in the XPS seems not to be problematic. The reason is the large area of the shear plane. In the most critical cases the shear stresses in the XPS reached around $50 \%$ of the nominal shear strength of the XPS $\left(\tau_{\text {nom }}=150 \mathrm{kPa}\right)$. The shear stresses in the XPS might become of critical concern in case of heavier and larger buildings (this was noticed in case of RC building with the plan layout 14/40 m lying on the XPS 400-L layer and soil type A) and in case of reduced area of the XPS under foundations (e.g. strip foundations - Figure 9). Another observing quantity is the horizontal top displacement of the building which is defined as the sum of the horizontal displacement at the XPS level and the horizontal displacement at the top (roof) level $(\mathrm{H})$ of the building. The latter is caused by the building sway (rotation) which is a consequence of the vertical deformability of the XPS. In most cases the obtained maximum horizontal top displacements of the building are smaller than the limit value set to $0.2 \%$ of the building total height $(\mathrm{H})$.

In Figure 9 the effect of area of the XPS under building foundations is presented. This case roughly simulates the structural variants with strip foundations lying on the XPS layer. In this case of the study it was considered that the area of the XPS under foundations covers $50 \%$ of the total plan area of the building. The investigated models were the structures made of different materials and with plan layout dimensions 8/14 m lying on the XPS 400-L layer and soil 

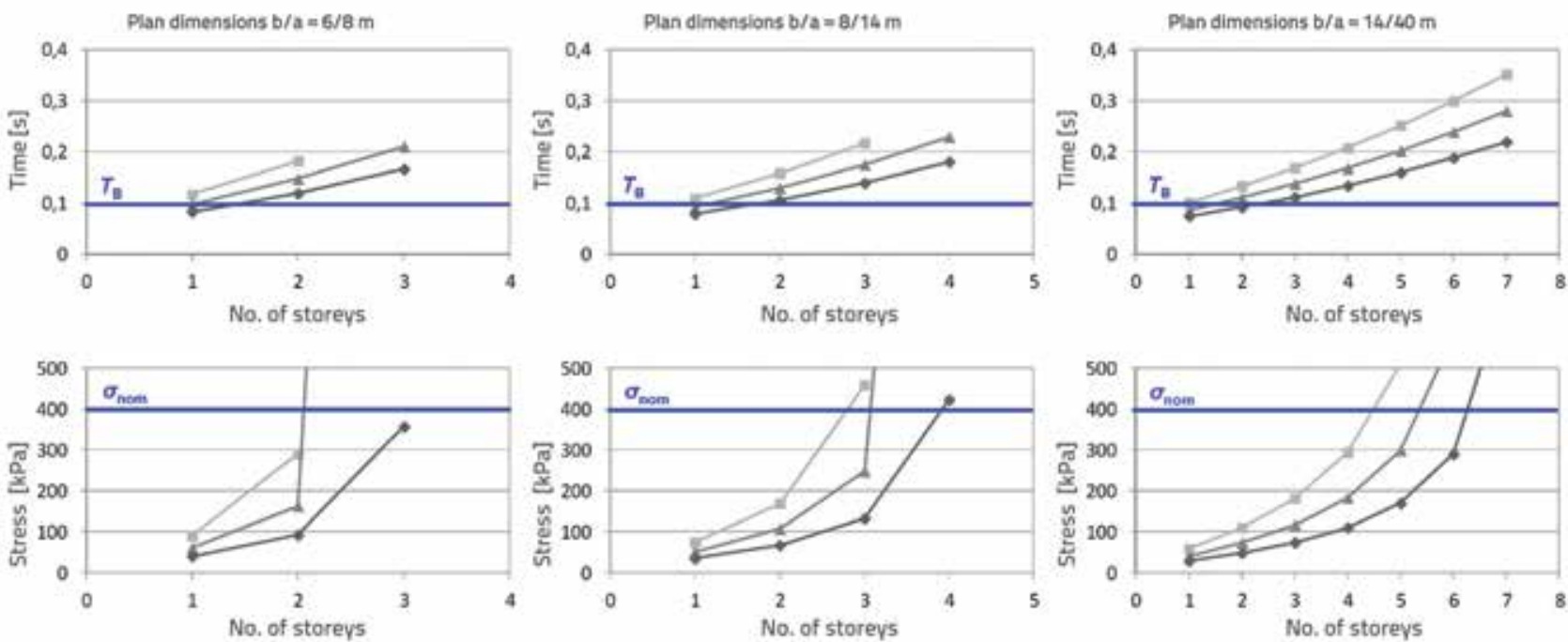

Legend: $\quad$ - w- reinforced concrete $\neq$-masonry $\leftrightarrow$-wood

Figure 7. Periods of vibration (above) and maximum edge compressive stresses (below) for different floor plan layout dimensions and materials of the superstructure founded on the XPS 400-L layer and the soil type A
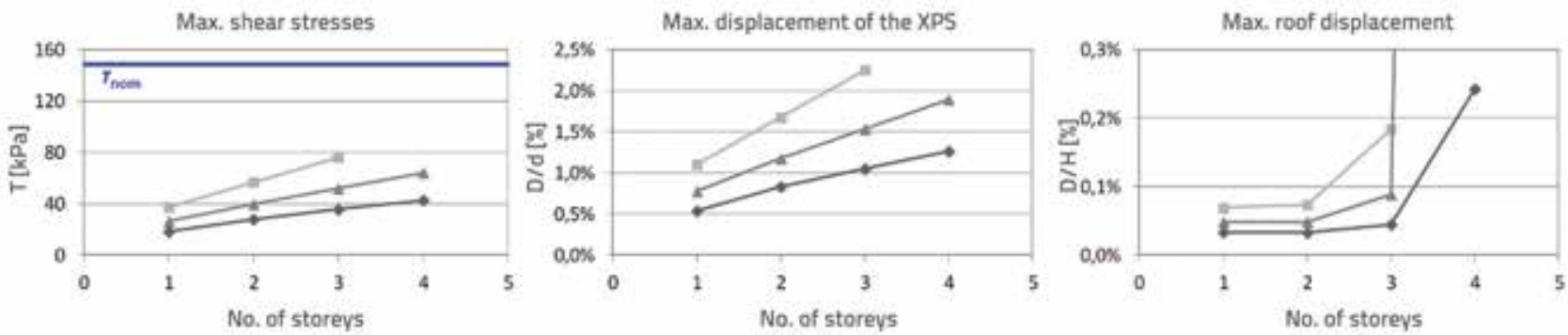

Legend: - *t- reinforced concrete *-masonry - wood

Figure 8. Maximum shear stresses and horizontal displacements of the XPS (XPS 400-L) and of the superstructure made of different materials and with floor plan dimensions $8 / 14 \mathrm{~m}$ founded on the soil type $A$
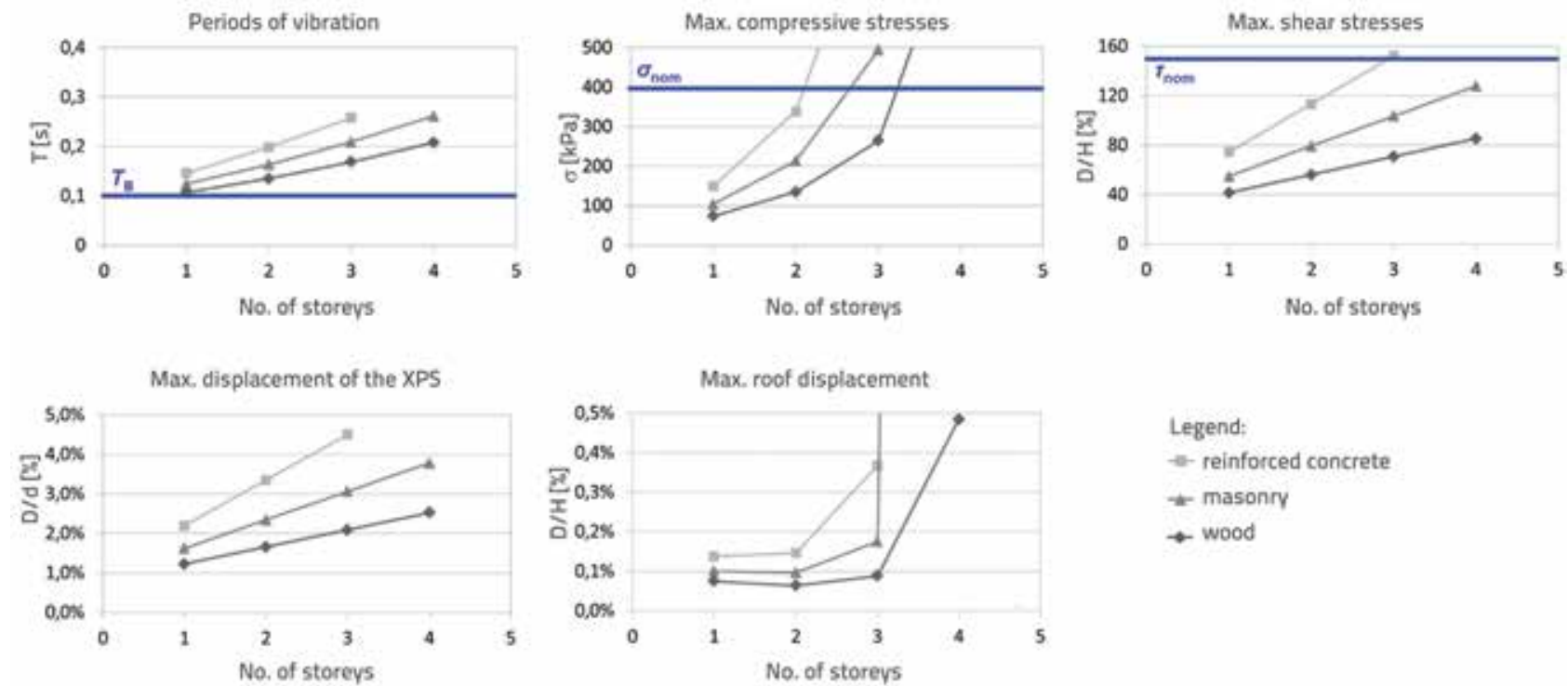

$$
\begin{aligned}
& \text { Legend: } \\
& \text {-- reinforced concrete } \\
& \text { - masonry } \\
& \text { - wood }
\end{aligned}
$$

Figure 9. Periods of vibration, maximum stresses and horizontal displacements for the superstructure made of different materials and with floor plan dimensions $8 / 14 \mathrm{~m}$ and strip foundations of area equal to $50 \%$ of the total plan lying on the XPS layer 

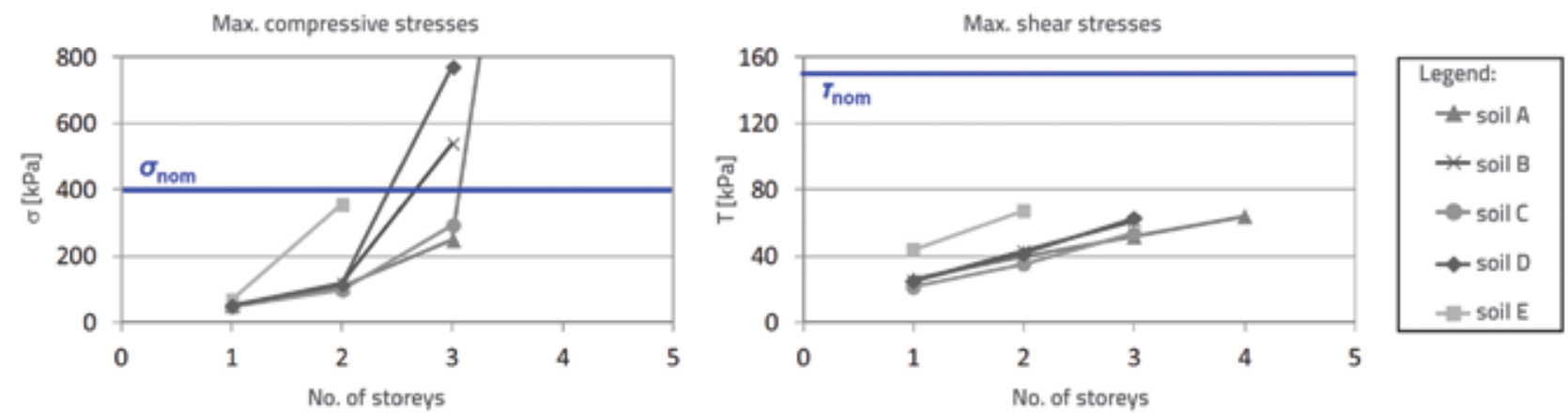

Figure 10. Maximum edge compressive and shear stresses in relation to ground soil type for masonry superstructure with $8 / 14 \mathrm{~m}$ floor plan dimensions lying on the XPS layer
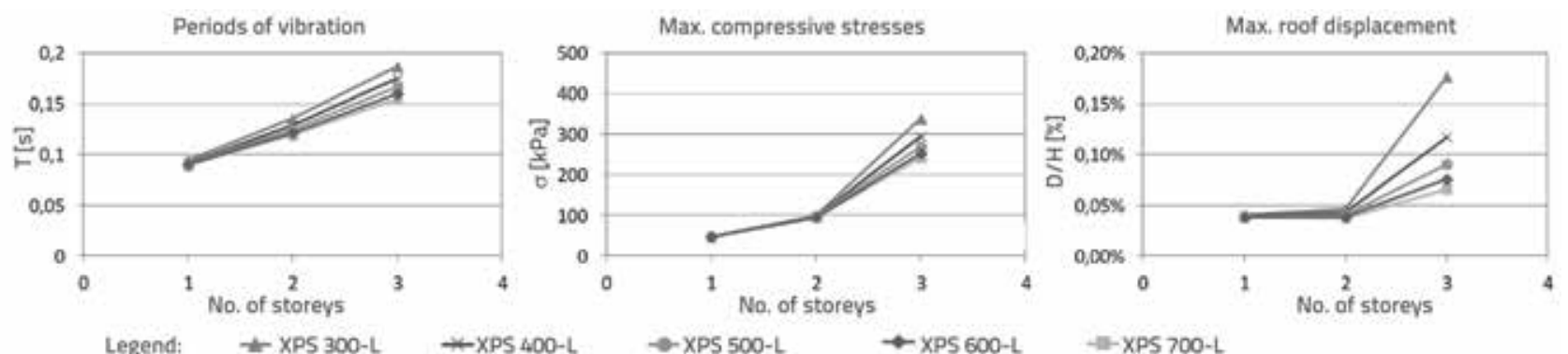

Figure 11. Periods of vibration, maximum edge compressive stresses and maximum horizontal top displacements in relation to the XPS type for masonry superstructure with $8 / 14 \mathrm{~m}$ floor plan dimensions founded on the soil type $C$

type A. In comparison with the structural variant founded on the XPS covering the total plan area (Figures 7 and 8) it should be noted that in all analysed cases the calculated periods of vibration are larger and similarly also the maximum compressive stresses increased. It should be emphasized, that in the case of masonry buildings also the maximum acceptable number of storeys is reduced from 3 to 2 . Taking into account the all assumptions considering in performed simplified analysis we should be aware that the actual maximum compressive stresses could be even larger than the calculated ones. Observing the shear stresses in the XPS and the horizontal displacements even greater increase (factor 2) could be noticed.

Figure 10 shows the effect of soil type for the selected material (masonry walls + light-weight slabs) and floor plan dimensions $(8 / 14 \mathrm{~m})$ of the superstructure lying on XPS 400-L layer. Observing the maximum compressive stresses in the XPS it can be seen that stiffer soils in general allow higher buildings than the softer ones. In the presented case on soil type E, D and B only two-storey buildings are allowed, while on soil type $A$ or $C$ three-storey buildings are possible. Similarly, the maximum shear stresses in the XPS under the building of selected height were obtained in case of softer soil conditions.

Figure 11 presents the seismic behaviour of a brick masonry building with floor plan dimensions $8 / 14 \mathrm{~m}$ founded on soil type $C$ and the XPS layers of different strength classes (XPS 300-L, XPS 400-L, XPS 500-L, XPS 600-L and XPS 700-L). It is shown that the building lying on stiffer XPS layer has shorter period of vibration (up to $20 \%$ for observed 3-storey building), smaller edge stresses (up to $40 \%$ for observed 3-storey building) and smaller top displacements (up to 2.7 times for observed 3-storey building). In comparison with the structure lying on the softer XPS layer the behaviour of the structure lying on the stiffer XPS layer is much better. In all analysed cases the maximum horizontal top displacements of the building are smaller than the limit value $0.2 \%$ of the building total height $(\mathrm{H})$. The maximum compressive stresses in the XPS are in all analysed cases smaller than the XPS nominal compressive strengths $\left(\sigma_{\text {nom }}\right)$. The exception is the case with the softest considered XPS (300-L) where the maximum obtained compressive stresses in the XPS slightly (for $13 \%$ ) exceed the $\sigma_{\text {nom }}$.

\section{Conclusions}

The results obtained in the study have shown that the designers of multi-storey buildings founded on the thermal insulation layer under the foundation slab should pay additional attention to the seismic behaviour of such structures. It was shown that inserting of the thermal insulation layers under the building's foundation changes its dynamic characteristics. We should be aware that in earthquake prone areas such a technique of ensuring the uninterrupted thermal envelope around the building could deteriorate the structural seismic response, thus the suitability of such foundation system needs 
to be verified, and appropriate solutions found. Observing results obtained in the study and taking into account the all assumptions considering in the performed simplified analysis, the following detailed conclusions may be drawn:

- In case of stronger seismic excitation the maximum compressive stresses in the thermal insulation layer (e.g. XPS) under the foundation slab could exceed the XPS nominal compressive strengths. In the investigated cases such occurrences were detected already in the cases of buildings with more than two or three storeys. In all analysed two-storey building models the compressive strength in the XPS was never reached.

- The control of maximum shear stresses and maximum horizontal displacements at the XPS layer proved not to be problematic. The reason is the large area of the shear plane and consequently the large shear stiffness of the XPS layer. The shear stresses in the XPS might become of critical concern in case of heavier and larger buildings and/ or in case of reduced area of the XPS under foundations (e.g. strip foundations). In the latter case the maximum allowed number of storeys could decrease.

- In case of applying the XPS layer under the foundation slab the system's period of vibration elongates and could reach the spectrum plateau (constant acceleration range) where the seismic forces are larger. Consequently, the stresses or displacement of the superstructure might exceed the design or allowable nominal values leading to undesirable damage of structure or its non-structural elements.

- In case of severe earthquake load also the horizontal top (roof) displacement of the building could be substantial. It should be noted that in our study the top displacement is caused only by the building sway (rotation) which is a consequence of the vertical deformability of the XPS.

- Taking under observation only the amplifications due to the insertion of the insulation under the foundation slab it was found out that the amplifications take the largest values in case of buildings founded on stiff soils while they are negligible in case of very soft soils.

- The XPS nominal compressive strength and stiffness are two essential parameters for designing the XPS layer particularly in case of slender buildings where the edge compressive stresses rapidly increase. In such cases the application of higher strength class of the XPS is recommended. Such XPS has also larger elastic modulus what reduces the rocking of the superstructure.

- For the building with short period of vibration $\left(T<T_{B}\right)$ it is better to be founded on stiffer XPS layer. Such building has shorter period of vibration, smaller seismic forces, smaller edge stresses in the XPS and smaller horizontal roof displacements.

- In case of building with longer period of vibration $\left(T \geq T_{C}\right)$ except the increase of absolute horizontal displacements, the potentially negative influences of inserting the insulation under the foundation slab could not be expected.

In terms of maximum obtained stresses in the XPS we can therefore conclude that for smaller plan layouts the maximum acceptable number of storeys is limited to 2 or 3, while it is larger ( 4 and more) in case of larger plan layouts, depending on the applied structural material (mass). The listed findings present the preliminary results based on the simplified seismic analyses. In the presented study the effect of the superstructure's flexibility has not been considered. It will be taken under consideration in our further research where also a complex parametric study of detailed nonlinear dynamic seismic response of real (flexible) superstructures lying on the XPS layer is planned. In our further work also the data about the cyclic behaviour of the XPS material will be experimentally determined, what has not been yet researched in the relevant literature.

\section{Acknowledgements}

The presented research was supported by the applicable research project of Slovenian Research Agency, project title "Safety of Passive Houses subjected to Earthquake", project number: L5-4319.

The authors are also grateful for funding and all the support provided by the company FIBRAN NORD d.o.o. The financial support of other project's co-funders (Gradbeni inštitut ZRMK; podjetje DULC, strojne instalacije in inženiring; Baza Arhitektura) is also gratefully acknowledged.

\section{REFERENCES}

[1] Zagorec, M., Josipović, D., Majer, J.: Mjere uštede toplinske energije u zgradama, GRADEVINAR 60 (2008) 5, p.p. 411-420.

[2] Feist W.: Life-cycle energy balances compared: low-energy house, passive house, self-sufficient house, Proceedings of the international symposium of CIB W67, Vienna, Austria, pp. 18390, 1996.
[3] Lang, G.: Study on the Development of Passive House Trends in Europe 2010 - 2021, http://www.langconsulting.at/index. php/en/research/32-basic-research/222-trends-2010-2021, 02.03.2013.

[4] Schnieders, J., Hermelink, A.: CEPHEUS results: measurements and occupant's satisfaction provide evidence for Passive Houses being an option for sustainable building, Energy Policy, 34, pp. 151-171, 2006. 
[5] Feist, W.: Wärmebrücken und Tragwerksplanung - die Grenzen des wärmebrückenfreien Konstruierens, Protokollband Nr. 35, Passivhaus Institut, 2007.

[6] Molin, A., Rohdin, P., Moshfegh, B.: Investigation of energy performance of newly built low-energy buildings in Sveden, Energy and Buildings, 43, pp. 2822-2831, 2011.

[7] Feist, W., Schnieders, J., Dorer, V., Haas, A.: Re-inventing air heating: Convenient and comfortable within the frame of the Passive house concept, Energy and Buildings, 37, pp. 1186-1203, 2005.

[8] Keul, A.G.: Vrednotenje večnadstropnih avstrijskih pasivnih stanovanjskih zgradb po vselitvi / Post-occupancy Evaluation of Multistorey Austrian Passive Housing Properties, AR, Arhit. razisk., 2, pp. 47-52, 2010.

[9] Mlecnik, E., Schtze, T., Jansen, S.J.T., de Vries, G., Visscher, H.J., van Hal, A.: End-user experiences in nearly zero-energy houses, Energy and Buildings, 49, pp. 471-478, 2012.

[10] Hauge, Å., Thomsen, J., Berker, T.: User Evaluation of Energy Efficient Builidings - Literature Review and Further Research, Proceedings of Renewable Energy Conference 2010, Trondheim, Norway, 2010.

[11] Feist, W.: Das Passivhaus - Baustandard der Zukunft? Protokollband Nr. 12, Passivhaus Institut, 1998.

[12] Schwarzmüller, E., Fuhrmann, W., et al.: Warmebrücken Luftund Winddichte, Energie Tirol, Innsbruck, 1999.

[13] Feist, W.: Wärmeverluste durch das Erdreich, Protokollband Nr. 27, Passivhaus Institut, 2004.

[14] Bosiljkov, V., Page, A. W., Bokan-Bosiljkov, V., Žarnić, R.: Evaluation of the seismic performance of brick masonry walls. Structural Control \& Health Monitoring, 17, pp. 100-118, 2010.

[15] Kitek Kuzman, M., Grošelj, P.: Wood as a construction material: comparison of different construction types for residential building using the analytic hierarchy process. Wood research, 57, pp. 591-600, 2012.

[16] Fischinger, M., Isaković, T.: Potresna izolacija pri novogradnjah in sanacijah $A C$ mostov: končno poročilo, Univerza v Ljubljani, Fakulteta za gradbeništvo in geodezijo, Ljubljana, 2001.

[17] Skinner, R. I., Robinson, W. H., McVerry, G. H.: An introduction to seismic isolation, John Wiley \& Sons, Chicester, England, 1993.

[18] Kilar, V., Koren, D.: Potresna izolacija zgrad kao alternativa za gradnjo na potresnih območjih, Gradbeni vestnik, 56, pp. 307$318,2007$.
[19] Koren D., Kilar, V.: Torzija potresno izoliranih konstrukcija nepravilnoga tlocrta, GRADEVINAR 60 (2008) 2, p.p. 99-108.

[20] Zbašnik-Senegačnik, M., Vrančić, T.: Velike gradevine građene kao pasivne kuće. Građevinar, 63, pp. 903-906, 2011.

[21] Gazetas, G., Anastasopoulos I., Adamidis, O., Kontoroupi, Th.: Nonlinear rocking stiffness of foundations. Soil Dynamics and Earthquake Engineering, 47, pp. 83-91, 2013.

[22] Ryan K.L., Chopra, A.K.: Estimating bearing response in symmetric and asymmetric-plan isolated buildings with rocking and torsion. Earthquake Engineering and Structural Dynamics, 35, pp. 1009-1036, 2006.

[23] Gelagoti, F., Kourkoulis, R., Anastasopoulos, I., Gazetas, G.: Rocking isolation of low-rise frame structures founded on isolated footings. Earthquake Engineering and Structural Dynamics, 41, pp. 1177-1197, 2012.

[24] CEN, European Committee for Standardization: European standard EN 826 : Thermal insulating products for building applications - Determination of compression behaviour, 1996.

[25] CEN, European Committee for Standardization: European standard EN 12090 : Thermal insulating products for building applications - Determination of shear behaviour, 1997.

[26] Kilar, V.: Statika II. z osnovami konstrukcij: učbenik za študente arhitekture, Univerza v Ljubljani, Fakulteta za arhitekturo, Ljubljana, 2013 (v tisku).

[27] Podhorsky, I.: Nosive konstrukcije, Udžbenik za studij arhitekture, Golden marketing - Tehnična knjiga Zagreb, Arhitektonski fakultet Sveučilišta u Zagrebu, Zagreb, 2003.

[28] Bokan Bosiljkov, V.: Poročilo o rezultatih preiskav ugotavljanja obnašanja proizvodov FIBRAN pri tlačni in strižni obremenitvi, Laboratorij Katedre za preizkušanje materialov in konstrukcij, Fakulteta za gradbeništvo in geodezijo, Ljubljana, 2013.

[29] CEN, European Committee for Standardization: European standard EN 1998-1 - Eurocode 8, Design of structures for earthquake resistance - Part 1: General rules, seismic actions and rules for buildings, 2005.

[30] SIST. Nacionalni dodatek k SIST EN 1990 (2005): Evrokod Osnove projektiranja - Nacionalni dodatek SIST EN 1990:2004/ A101: 2005, Slovenski inštitut za standardizacijo, 2005.

[31] Fajfar, P.: Dinamika gradbenih konstrukcij, Univerza Edvarda Kardelja v Ljubljani, Fakulteta za arhitekturo, gradbeništvo in geodezijo, Ljubljana, 1984.

[32] Katalog proizvodov FIBRANxps, proizvajalca Fibran Nord d.o.o.: http:/ / www.fibran.si/frontend/articles. php?cid=121\&view=0, 05.03.2013. 